\title{
AN ANALYSIS OF SPEECH ACT USED IN HARRY POTTER AND THE GOBLET OF FIRE MOVIE
}

\author{
Putri, I.A.P.A.D.P. \\ English Education Department, Ganesha Universityof Education \\ e-mail: dhayudharma@gmail.com \\ Ramendra, D.P. \\ English Education Department, Ganesha Universityof Education \\ e-mail: putu.ramendra@undiksha.ac.id \\ Swandana, I W. \\ English Education Department, Ganesha University of Education \\ e-mail : wayan.swandana@undiksha.ac.id
}

\begin{abstract}
This research aimed at analyzing the speech act used in Harry Potter and the Goblet of Fire movie. This research was conducted in descriptive qualitative. The primary sources of data were utterances in Harry Potter and the Goblet of Fire movie. This research also used its movie script as a secondary source. The data were collected through observation and documentation techniques and analyzed through the stages of data reduction, data display, verification, and conclusion. The research result showed that the utterances have locutionary act or took the form of declarative, interrogative, imperative and exclamation and those were used to express the direct/indirect illocutionary act of declarative, representative, expressive, directive and commissive. Besides, the use of the forms and their illocutionary acts brought about the result of the perlocutionary acts of belief, annoyance, surprise, enlightenment, confirmation, rejection, obedience, information, happiness/satisfaction, and action. This research enriched the knowledge and understanding of the variety of structures, functions, effects, and classification of language in society.
\end{abstract}

Keywords: speech act, locutionary act illocutionary act, perlocutionary act

\section{INTRODUCTION}

Discussing language and communication in society is closely related to Pragmatics, especially Speech Act. Speech act was introduced by L.J. Austin in his book entitled "How to do Thing with Word?" which was published in 1962. Austin found that the philosophers assumed the utterances produced by people are used to give a statement or description about something whether it was true or false while grammarians stated that not all sentences are used to describe something (1962: 1-3). Based on those statements, Austin developed two kinds of utterances namely constative utterance and performative utterance. The utterance used to state, describe or report conditions and situations surrounding is called as constative utterance meanwhile performative utterance is the utterance that used to make someone taking an action toward the utterance spoken by the speaker (1962: 3-6). 
Those kinds of utterances made the term speech act appeared. The term speech act became popular when John R. Searle expressed his opinions and understanding about the speech act in a book titled Speech Acts. An Essay in the Philosophy of Language (1969). Searle defined the speech act as a theory that examined the meaning of language based on speech relations with the actions taken by the speaker. According to Mey (1994: 111) speech act is an action happening in the world, that is, they bring about a change in the existing state of fairs (stated in Zumaroh: 2012). Meanwhile, Yule described that speech act is an action performed via the utterances (1996: 47). In conclusion, speech act is the theory about the utterances which can be used to change, state, express, even it can make someone commit and act toward the utterances said by the speaker.

Then Austin (1962:108) enhanced speech act became three acts in which it simultaneously performed when someone uttering a sentence, those acts are locutionary act, illocutionary act, and perlocutionary act. Locutionary act is the structure of the utterance in which it had the literal meaning. There are four structural forms namely declarative form, interrogative form, imperative form and exclamation form. Declarative form is the form of utterance which consisted of statement or information about something. The utterance in the form of question is called as interrogative form. Meanwhile, the imperative form is the utterance in the form of order, invitation, warning, congratulation, etc. Exclamation form is the utterance used to express speaker feeling about something spontaneously.

Illocutionary act is the function of the utterance itself. Searle stated there are five types of utterance based on their function such as declarative (the utterance used to change the situation) which classified into declaring, confirm, bless and dismiss. The second type is representative in which the utterance produced by the speaker used to represent the surroundings in order to make the listener believe in what the speaker said. It can be categorized as six sub-function such as swear, inform, assert, deny, claim, describe and report. The third function is expressive in which the speaker produced the utterance to express his/her feeling. Expressive consisted of condoling, praise, thank, regret, congratulate, criticize, complain and swear. The utterance also had a function to make the listener doing something as the speaker said is called as directive. Directive can be classified into five sub-functions namely ask, invite, order, request, and suggest. And the last type of utterance was to show the commitment of speaker about some future action is called as commit. Refuse, promise and commit are sub-function of commit itself.

Perlocutionary act is the effect of the utterance produced by the speaker toward the listener. There are some effects commonly appeared when the speaker was produced the utterance such as it can make the listener believes, annoyed, afraid, enlighten, inspires, confirms, rejects, obedient, informs, understands, happy/satisfied, surprised and it also can make the listener doing something.

Parker (1986: 17-20) also gave his contribution about speech act in which he classified speech act into direct speech act and indirect speech act. Direct speech act is a speech act which has similarity between structural form and function of the utterance itself. Whereas indirect speech act is speech act which its function does not have conformity with its structural form.

The movie can be a good field in finding speech acts because it represented various speech acts in different situation which meant there were lots of utterances produced by the characters. People also can find various forms and functions of the 
language used in the movie. The movie is a type of visual communication which used moving picture and sound to tell stories or help people to learn.

There are some genres of movie namely action, adventure, animated, comedies, drama, tragedies, family, horror, romantic, thrillers, fantasy, etc. Based on its history, the first movie commercially published in 1895 and nowadays there were lots of movies have been produced. In this study, the researcher interested to analyze speech act used in a fantasy movie entitled Harry Potter and the Goblet of Fire. Harry Potter and the Goblet of Fire movie was published in 2005 which directed by Mike Newell and produced by Warner Bros. Pictures. This movie was the fourth sequel of the Harry Potter movie series which is actually adapted from J.K. Rowling's novel with the same title. The script of this movie is written by Steve Kloves.

The movie was about Harry Potter's life in Hogwarts (the school of the wizard) in which he unexpectedly was chosen by the Goblet of the Fire to compete in the Triwizard Tournament which is the legendary event in which three magical schools competed across three dangerous challenges. Harry must complete those dangerous tasks in that tournament in which he saw his friend was killed in the final task and he also saw the revival of Voldemort.

There were several reasons and considerations of the researcher in choosing Harry Potter and the Goblet of Fire as the object of this research. First of all, this movie nominated in 43 awards and won 13 awards. This movie nominated in Academy Awards in 2006 for Best Art Direction. In that year, this movie also won as Best Production Design and nominated for Best Achievement in Special Visual Effects at BAFTA (British Academy Film and Television Art) Award. Harry Potter and the Goblet of Fire is one of the best-reviewed installments within the series, being praised for the higher level of maturity and sophistication of its characters, plotline, screenplay and the performances of the lead actors.

Harry Potter and the Goblet of Fire movie also have a moral value that can be learned such as be a wise person, do not be a person who judges someone by his/her appearance, be a person who gives without expecting in return, be a responsible person, etc. In addition, this movie is really interesting because it presented lots of conflicts in which there were so many utterances spoken by the characters to deliver the message of that story.

Furthermore, the researcher wanted to know how important language used in Harry Potter and the Goblet of Fire movie. Because based on the previous researches has been conducted before, the researcher found that the previous researches only focused on one function of speech acts such as directive only or commissive only without included about their forms and effects toward the listener. There were also not many types of research about Harry Potter and the Goblet of Fire movie. Moreover, some of them did not include an explanation about the classification of speech acts itself.

In order to develop the previous researches and found various forms, function, effects, and classification of speech act, the researcher conducted the study about "An Analysis of Speech Act Used in Harry Potter and the Goblet of Fire Movie". This research elaborated the speech act used in Harry Potter and Goblet Fire movie in which it included the analysis of three related acts of the utterances produced by the characters especially the structural form of the utterances (locutionary act), function of the utterances (illocutionary act) and the effect of the utterances toward the listener 
(perlocutionary act). It also elaborated the classification of the utterances whether those are direct speech act or indirect speech act.

Based on the explanation above, the researcher found that sometimes the utterances produced by the speakers did not only have a literal meaning but it has the function that can give an effect toward the listeners. Several utterances also have the form which reflected its own function while the others have a difference between its function and its form. Therefore, the researcher interested in elaborate speech act used in utterance especially in Harry Potter and the Goblet of Fire movie.

\section{METHODE}

The type of research used by the researcher in this paper descriptive qualitative research in which the data collected from this study took the form of words rather than numbers. According to Bogdan and Taylor (in Moleong, 2007:3) descriptive qualitative research was a research procedure that produces descriptive data in the form of written words of people or observed behavior.

Research subjects in this research were the characters who play a role in Harry Potter and the Goblet of Fire movie including the Old Man (care-taker of the empty house), Voldemort, Wormtail, Barty Junior, Harry Potter, Hermione, etc. Meanwhile, the object of research in this study is conversations between actors/characters in Harry Potter and the Goblet of Fire movie that contains utterances.

In accordance with this research's title 'An Analyze of Speech Act Used in Harry Potter and the Goblet of Fire Movie' the data collected by the researcher were in the form of utterances produced by the characters found in the conversation on Harry Potter and the Goblet of Fire movie in which the data had been analyzed the three related acts (locutionary act, illocutionary act, and perlocutionary act) through the theory proposed by Austin included five types in illocutionary act (declarative, representative, expressive, directive and commissives) based on Searle's theory. The data also had been classified into direct speech act or indirect speech act according to Parker's theory.

In this study, the researcher used two data sources, namely primary and secondary sources. The primary source was a source that can provide data directly to the researcher in which in this study the main data source used by the researcher was conversations among the characters in Harry Potter and the Goblet of Fire movie with durations of two hours and forty-five minutes thirty-one seconds. Meanwhile, secondary sources were sources that do not directly provide data to the researcher such as notes or another document. In this research, the researcher used the script of the Harry Potter and the Goblet of Fire movie written by Steven Kloves as a secondary source to support and facilitate the researcher in understanding and analyzing the utterance were produced by the research subjects.

The techniques of collecting data are the ways used by the researcher to collect data needed in research. The techniques used by the researcher in this study were observation and documentation. Observation is a basic technique commonly used in all sciences in which the technique is a deliberate and systematic observation of the symptoms that occur for later recording (Sugiyono, 2008:310). The purpose of observation is to see or observe changes in social phenomena and symptoms that grow. In this study, the first technique used by the researcher was the observation technique however the researcher did not go directly to the field in which the researcher only observed the conversation of the research subjects through the movie being studied, 
namely Harry Potter and the Goblet of Fire movie. In this case, the researcher was acted as an observer to observe the research object, the conversations (which contain utterances) performed by the research subject.

To obtain accurate data, the researcher observed the subject itself in terms of gesture, behavior, expression, and intonation to support the analysis carried out by the researcher. In addition to observing movies, the researcher also read the movie script itself to understand the utterances produced by the research subjects. It conducted to get more accurate data that can support the analysis of this research.

The second technique used by the researcher was documentation techniques. During the observation, the researcher made important notes about utterance produced by the speaker, time when the utterance was produced, who the speaker is, who the listener is, situation (included condition, behavior, gesture, expression, intonation) of the speaker and the listener when the utterance was produced. These records or notes were used to support sorting necessary data and unnecessary data and to facilitate the researcher to analyze the three related acts (locutionary act, illocutionary act, and perlocutionary act) by using the theory proposed by Austin included five types in illocutionary act (declarative, representative, expressive, directive and commissives) based on Searle's theory. The data also had been classified into direct speech act or indirect speech act according to Parker's theory.

In addition, the researcher also used written documents related to this study that was scripts from Harry Potter and the Goblet of Fire movie. Then the researcher compared the notes that had been made previously with the scripts from Harry Potter and the Goblet of Fire movie to get accurate data and in accordance with the existing problems.

The techniques of analyzing data used by the researcher in this study were data reduction, data display and verification, and conclusion.

According to Miles and Huberman (in Pambudi, 2017:41), data reduction from taking and selecting the right data that appears in written-up field notes or transcriptions based on standard criteria were needed. In this study, the data collected previously from the observations on the subjects of the research were compared to the utterances contained in the movie script. By comparing data from different sources, it made easier for the researcher to choose necessary and unnecessary data.

Data display is describing the process of a set of structured information that gives the possibility of drawing conclusions and taking action (Miles and Huberman in Pambudi, 2017:41). Based on the definition above, the researcher described and analyzed the data that had been collected previously in which in this study the researcher presented the description, explanation, and analysis of three related acts of utterances produced by the characters especially the structural form of utterances (locutionary act), function of utterances (illocutionary act) and the effect of utterances toward the listener (perlocutionary act). It also elaborated the classification of utterances whether those are direct speech act or indirect speech act.

After describing and analyzing the data, the researcher then verifies whether the data were correct or not. In this case, the researcher examined the data and analyzed that based on the sources and theories used which as previously explained that this study used movie and movie scripts of Harry Potter and the Goblet of Fire as sources while for the theories the researcher used are Austin's theory about the three related act supported by Searle's theory especially about five types of illocutionary act (declarative, representative, expressive, directive and commissive) and Parker's theory about the 
classification of speech act (direct speech act and indirect speech act). Besides that, the researcher also used theories from other experts who supported those theories.

The researcher made conclusions after the data and analysis are in accordance with the sources and theories in which the researcher added some of her opinions toward the outcome found.

In validating the data found, the researcher used data triangulation in which according to Sugiyono $(2008: 272)$ data triangulation in credibility testing was interpreted as checking data from various sources in various ways and at various times. He stated that there were three ways to test the validity of data which could be called source triangulation, triangulation of data collection techniques and time. Based on these explanations, the researcher used three ways to test the validity of data that had been obtained previously, namely time triangulation, technique triangulation, and source triangulation.

\section{FINDING AND DISCUSSION}

Based on the observation had been conducted by the researcher, there were 40 data in form of utterance were found and had been categorized into locutionary act, illocutionary act, perlocutionary act, direct speech act, and indirect speech act.

The researcher used the code HPGF/Ut1/00.00.00 to identify the title of the movie, the sequence of the utterance and the time when the utterance was produced. HPGF indicates the name of the movie used in this study namely Harry Potter and the Goblet of Fire, Ut1 indicates the sequence of utterance while 00.00 .00 indicates the time of utterance when it was produced. The following are description, explanation, and analysis of data found.

(1) HPGF/Ut1/00.01.48

Old man: Bloody kids!

Situation: The old man was an empty housekeeper then one night he realized that the lights in one of the rooms of the house were lit. He thought that naughty kids turned on the lights in that house that made him angry and swear.

Based on its structural form, the utterance (1) can be categorized as exclamation form because the utterance was used to express the speaker's feeling. It also can be seen from the intonation used by the speaker (Old Man) when produced the utterance in which he used rising intonation and the voice is quite loud. In this scene, the speaker (Old Man) was angry because he thought there were naughty kids who turned on the lamp in the house that he guarded.

From its structure, it can be seen that the literal meaning of the utterance (1) is kids who are bleeding. In this case, this utterance does not contain an intention that can affect the listener. However, the speaker does not use the utterance to state that the naughty kids who he thought were entered the house he guarded were bleeding. The utterance is actually used to swear those kids, and it is categorized as implicit because it does not use an explicit performative verb swear.

Swearing in illocutionary act is included in expressive type usually used to express strong feelings of the speaker through the use of blasphemous or obscene language. Swearing is produced when the speaker feels upset, angry, disappointed or even dislike someone's behavior. In the scene above, the speaker (Old Man) produces the utterances (1) because he felt annoyed and dislikes the kids' behavior who often entered the empty house that he guarded without permission. Thus, he actually intended to say "(I curse you all) bloody kids". 
Usually, when the speaker produced the utterance in the form of swearing, the effect that must be happened is the listener will feel annoyed when they heard that utterance. However, there is no effect of the utterance (1) in the scene above because it does not have any listener when the utterance was produced by the speaker (Old Man).

Based on the explanation above, it can be concluded that the utterance (1) is an exclamation form because it used to express the speaker's feeling when the speaker was angry, annoyed or dislike the behavior of those naughty kids. According to Parker (1986: 17-20), the speech act which has conformity can be categorized as a direct speech act. Therefore, the utterance (1) can be said as a direct speech act of swearing.

(2) $\mathrm{HPGF} / \mathrm{Ut} 2 / 00.02 .45$

Voldemort: How fastidious you've become, Wormtail. As I recall, you once called the nearest gutter pipe home. Could it be that the task of nursing me has become wearisome for you?

Wormtail: Oh no, no, no, my Lord Voldemort. I only meant... perhaps if we were to do it without the boy.

Situation:

Voldemort, Wormtail and Unknown Man held a meeting in an empty house discussed the secret plan that they will conduct immediately.

The utterance (2) was produced by the speaker (Voldemort) is classified as an interrogative form. The utterance (2) categorized as yes/no question because this question used rising intonation and stressed when it was produced.

In this scene, the speaker (Voldemort) was wanted to know whether or not nursing him who was not in a perfect body was a burden for the listener (Wormtail). Hence, that utterance can be categorized as a directive type of illocutionary act especially to ask the listener (Wormtail) about something. If it examined, that did not only use to ask something however it can be used as the reminder for the listener about his obligation as the servant of the speaker who must look after him without any objection although that utterance did not explicitly use performative verb remind. Implicitly, through that utterance, the speaker wanted to say "I will remind that you are my servant so you cannot feel burdened in nursing me because that is your obligation". It can be proven by the utterance "as I recall, you once called the nearest gutter pipe home." that showed the listener (Wormtail) was just poor person who lived in a ditch before met with the speaker (Voldemort).

When the utterance (2) has been produced, the listener (Wormtail) gave confirmation as the response by saying "Oh no, no, no, my Lord Voldemort" that indicated the listener (Wormtail) did not mind in taking care of Voldemort who was not in a perfect body. It meant that the listener remembers his obligation as a servant.

From the explanation above, it can be concluded that the utterance (2) is direct speech act of asking because it can be proven by examining the structural form that was an interrogative form that reflected the function of that utterance in which it used to ask something hence the speaker will get a confirmation from the listener.

(3) HPGF/Ut3/00.02.50-00.02.54

Wormtail: Oh no, no, no, my Lord Voldemort. I only meant... perhaps if we were to do it without the boy. 
Voldemort: No! The boy is everything, it cannot be done without him and it will be done exactly as I say.

Situation: Voldemort accused Wormtail of feeling burdened in taking care of him who was in an imperfect condition. And it was denied by Wormtail because all he wanted was to give suggestion for Voldemort.

The utterance (3) has the meaning that the speaker (Wormtail) gave his opinion about the secret plan that they will do. Wormtail argued that they might be able to carry out the secret plan without the boy. Based on its meaning, that utterance can be classified as a declarative form because the speaker used it to state his opinion about their secret plan.

Through that utterance, the speaker (Wormtail) intended to provide a possibility that they can carry out the secret plan without involving the boy. In this study, that utterance categorized as a suggestion which is included in the directive type in illocutionary act. Thus, the speaker explicitly intended to say that "(I think) we can conduct our plan without the boy".

The effect occurred in this scene was a rejection of the listener (Voldemort). It can be seen in the dialogue above, Voldemort said "No!" to express his disapproval of the suggestion given by Wormtail. It meant that they did not have appropriate intention in which the listener (Voldemort) intended to conduct the secret plan by involving the boy because the boy has an important role in their plan.

The utterance (3) is classified as a direct speech act of suggesting because the function and structural form of the utterance has compatibility. It can be seen from the form of that utterance which is a positive declarative form that is produced by the speaker to express something, in this scene, the speaker was using that utterance to express his opinion about the possibility in conducting their secret plan.

(4) HPGF/Ut4/00.03.07

Voldemort: No! The boy is everything, it cannot be done without him and it will be done exactly as I say.

Unknown Man: I will not disappoint you, my lord.

Voldemort: Good. First, gather our old comrades. Send them a sign.

Situation: Wormtail tried to advise Voldemort about their secret plan which might be conducted without involving the boy however Voldemort did not approve it and said that the boy was very important and they had to carry out the plan as Voldemort's order. His order was obeyed by the Unknown Man in which he said that he will not disappoint Voldemort.

The utterance (4) is a negative form that can be categorized as a declarative form. The meaning of the utterance (4) was to tell that the speaker (Unknown Man) will not disappoint the listener (Voldemort). The speaker intended to say that "(I am committed) to not disappoint you, my lord". It can be seen that utterance had a function to pledge devotion to somebody or something. In illocutionary act, its function is called a commitment that included in commissive type of speech act. It can be proven by observing the middle and the final story of the movie in which it narrated that Voldemort and his man were successful in carrying out their plan by involving the boy. 
As a result of the utterance (4), the listener (Voldemort) felt happy and satisfied because the speaker (Unknown Man) will obey his orders. It was indicated by the utterance spoken by the listener (Voldemort) which in that scene Voldemort said "Good" to express his satisfaction. It also can be used as the evidence that the listener (Voldemort) believed in that utterance said by the speaker (Unknown Man).

As explained earlier, if the structural form of utterance reflected its function, that utterance can be classified as a direct speech act. However, if the utterance does not have conformity between the function and the structural form of the utterance itself, the utterance is called the indirect speech act. It can be concluded that the utterance (4) was classified as a direct speech act of committing because the function and structural form of the utterance are aligned in which that utterance is a declarative form used to express the commitment of the speaker (Unknown Man).

(5) HPGF/Ut5/00.03.11 - 00.03.14

Voldemort : Good. First, gather our old comrades! Send them a sign!

Situation: Voldemort gave an order to the Unknown Man and Wormtail to gather their comrades and send a signal to them after they understand that they will conduct their plan by involving the boy and they will obey all orders given by Voldemort.

The utterance (5) was an imperative form because that utterance used a verb in the form of bare infinitive and it consists of the instructions for the listeners (Unknown Man and Wormtail) given by the speaker (Voldemort). That utterance had meant that Voldemort wanted the Unknown Man and Wormtail to gather the comrades and send a signal to them. Examining from its meaning, the utterance (5) was an instruction used to make listeners (Unknown Man and Wormtail) gathering and sending signals to their comrades. Thus, he actually intended to say "(I order you to) first gather our old comrades and send them a sign!”.

That utterance can be classified as a directive type of illocutionary act in the form of an order. In this scene, the utterance above is included in the type of direct order because the utterance is said directly to the listener and contained imperative words that indicated it was an order. In addition, that utterance can be categorized as orders because there is because there are different positions between speaker and listeners. The speaker (Voldemort) has a higher position than the listeners (Unknown Man and Wormtail) in which the speaker is a boss while the listeners are subordinate and servant of the speaker (Voldemort).

It can be seen from its function and context, the utterance (5) can make the listeners (Unknown Man and Wormtail) obeying and doing something like the commands given by speakers (Voldemort). Although, there was no direct response from the listeners (Unknown Man and Wormtail) but in the middle until the ending of the movie, it can be proven that Unknown Man and Wormtail have done the order given by Voldemort so they can carry out their plans as the speaker's wants.

The utterance (5) was a direct speech act of order because it was an imperative form which is contained with the instruction of the speaker (Voldemort) and its function was to give an order to the listener. Therefore, it can be concluded that the utterance (5) was a direct speech act of order in which its structural form reflected its function. 


\section{CONCLUSION AND SUGGESTION}

Based on the explanation and analysis above, it can be concluded that in Harry Potter and the Goblet of Fire movie there are 40 data in the form of utterance which have been categorized into locutionary act, illocutionary act, perlocutionary act, direct speech act, and indirect speech act. The following are some details of the data that have been found by the researcher.

In locutionary act, there are around $45 \%$ of data included in declarative forms, $25 \%$ of data which included in interrogative and imperative forms and only $5 \%$ of data which included in exclamation forms.

In illocutionary act, the researcher found around 2,5\% of data included in the declarative specifically in the form of declare; $25 \%$ of data included in the representative in the form of information, assert, deny, claim, describe and report; $22,5 \%$ of data included in expressive, namely in the form of praise, thank, regret, congratulate, criticize, complain, and swear; $47,5 \%$ of data included in the directive in the form of ask, invite, order, and suggest; and $2,5 \%$ of data that is included in the commitments in the form of commit.

In perlocutionary act, the researcher found that there are several effects toward the listener that arise when the utterance is produced by the speaker, namely believe, annoyed, surprised, enlightened, confirm, reject, obedient, inform, happy/satisfied and do something.

In the direct speech act the researcher found around 92,5\% data while there were around $7,5 \%$ of data in the form of indirect speech act. This research is able to enrich the knowledge and understanding of the structures, functions, effects and classification of language in the society especially in speech act field. In addition, through this research, it is expected that other researchers can use this research as the references and will carry out further research, especially those who examine the speech act in the movie or different subject.

\section{REFERENCES}

Arikunto, Suharsimi. 2006. Prosedur Penelitian Suatu Pendekatan Praktik. Jakarta : Rineka Cipta.

Austin, J.L. 1962. How to Do Things with Words. London: Oxford University Press 1962.

Chaer, Abdul. 2010. Kesantunan Berbahasa. Jakarta: Rineka Cipta.

Cummings, Louise. 2005. Pragmatics: A multidisciplinary Perspective. New Jersey: Edinburgh University Press.

Moleong, Lexy.J., 2007.Metode Penelitian Kualitatif, Bandung: Remaja Rosda Karya.

Muhartoyo and Kristani, Keilly. 2013. Directive Speech Act in the Movie "Sleeping Beauty". Available at http://research dashboard.binus.ac.id/uploads/paper/document/publication/Proceeding/Hum aniora/Vol.\%204\%20No.\%202\%20Oktober\%202013/025_IG_Muhatoyo.pd f on Tuesday, 16th April 2019.

Pambudi, Nur Wahyu. 2017. An Analysis of Commissive Speech Act Used in the Vow (Pragmatics Study). Available at http://eprints.iainsurakarta.ac.id/769/1/Nur\%20Wahyu\%20Pambudi.pdf on Friday, 19th April 2019. 
Searle, John. R., 1969.Speech Acts. An Essay in the Philosophy of Language. London: The Syndics of the Cambridge University Press.

Wijaya, I Dewa Putu . 1996. Dasar-Dasar Pragmatik. Yogyakara: Penerbit Andi.

Yule, George. 1996. Pragmatics. New York: Oxford University Press

Zumaroh, Siti. 2012. The analysis of Speech Act Used in "Air Force One" Movie Script. Available at http://perpus.iainsalatiga.ac.id/docfiles/fulltext/12fea3ffe1a33fb8.pdf on Saturday, 27th April 2019. 